\title{
Effect of Carbamate and Pyrethroid Pesticide Residues on Cocoa-producing Soil, Sediment and Water of Owena River Basin Ondo State, Nigeria
}

\author{
AdegunAyodejiOluwole*, Akinnifesi Thompson A, Ololade Isaac A
}

Department of Chemical Sciences, AdekunleAjasin University, AkungbaAkoko, Nigeria

DOI:10.36348/sijcms.2020.v03i10.004

| Received: 13.12.2020| Accepted: 24.12.2020| Published: 30.12.2020

*Corresponding author:Adegun AyodejiOluwole

\section{Abstract}

This study investigated how carbamate and pyrethroid pesticide residues added to cocoa soil through agricultural activities related to the concentrations of pesticide residues in Owena river, Ondo State, Nigeria. Extractions from soil/sediment and water samples were obtained through ultrasonic bath extraction and liquid-liquid extraction respectively. The samples were analyzed with a gas chromatograph coupled to a mass spectrometry detector. The total mean carbamate pesticide residues level in dry season in the soil and sediment samples were $1.01 \pm 0.29 \mu \mathrm{g} / \mathrm{g}$ and $2.45 \pm 2.38 \mu \mathrm{g} / \mathrm{g}$ respectively. Their wet season level were $0.78 \pm 0.05 \mu \mathrm{g} / \mathrm{g}$ and $0.76 \pm 0.15 \mu \mathrm{g} / \mathrm{g}$. The dry season pyrethroid pesticide residues level in the soil, sediment and water were $2.61 \pm 1.87 \mu \mathrm{g} / \mathrm{g}, 1.20 \pm 1.33 \mu \mathrm{g} / \mathrm{g}$ and $<0.01 \mu \mathrm{g} / \mathrm{L}$ respectively. Their wet season observation were $0.70 \pm 0.25 \mu \mathrm{g} / \mathrm{g}$ and $0.42 \pm 0.25 \mu \mathrm{g} / \mathrm{g}$ for soil and sediment respectively. However, these pollutants were not found in the treated water.The mean level of these pollutants in the soil and surface water were below the former Nigerian Federal Environment Protection Agency maximum residue limit while their level in some of the sediment samples were higher than EU limit. This study, therefore, concluded that the soil, sediment and surface water in the study area were contaminated with carbamate and pyrethroid pesticide residues associated with cocoa farming around the river basin, although the treated water from the State water Works is safe for drinking. Therefore,the study recommended proper legislation and enforcement of laws on the control of these contaminants.

Keywords: Pesticides, carbamate, pyrethroid, pesticide residues, soil, sediment, drinking.

Copyright () 2020 The Author(s): This is an open-access article distributed under the terms of the Creative Commons Attribution 4.0 International License (CC BY-NC 4.0) which permits unrestricted use, distribution, and reproduction in any medium for non-commercial use provided the original author and source are credited.

\section{INTRODUCTION}

Synthetic organic pesticides are groups of chemicals that are hazardous to man [1]. They pose serious health concern to humans and the environment [2]. Diseases and deaths usually occur from exposure to pesticide poisoning [3]. The residues of these pesticides contaminate water bodies and this pollution has been an important problem globally. Surface and ground water are polluted as a result of pesticide residues from agricultural activities [4]. Pesticides are applied bycocoa farmers in Ondo state, Nigeria during the raining season for effective pest control. Every part of cocoa plant is sweet . The sweetness attracts mirids and bugs to attack the cocoa plants. The effective chemical application of pesticides could lead to incidences of their residues on non -targeted substances which will result in adverse effect on the health of human and the environment [5].

Carbamates are one of the main classes of synthetic organic pesticides that were used globally since their introduction into the market in the 1950s [6]. They are used annually on a large scale worldwide. The bioaccumulation potential of carbamates is very low and their metabolism and excretion are fairly rapid. They also exhibit short time toxicity [7]. They are known as hazardous chemicals to the environment and human health. They are included in the list of priority chemicals released by the Environmental Protection Agency in USA [9]. They are also included in endocrine disrupting compounds list [7-9]. The immediate toxic effect of carbamates is very similar to that of organophosphates. The recovery is however, comparatively rapid [9]. Spontaneous recovery without medical treatment occurs generally within 4 hours of an exposure which produced symptoms and signs of headache, light- headedness, dizziness, weakness, excessive salivation, nausea, and vomiting $[8,9]$.

Pyrethroid pesticides which replaced organophosphate pesticides recently are extremely toxic to fish They are also toxic to other aquatic benthic organisms [10]. They could also accumulate in aquatic 
plants and bioacumulate in fish [11]. The most toxic pyrethroid pesticide for fishes is deltamethrin [12]. The lethal effect of this pesticide damages their gills, changes their behaviour, accelerate their respiration processes, causes loss of coordination and convulsions [12]. Chronic symptoms after exposure to cypermethrinmay include brain and locomotory disorders, polyneuropathy and immuno-suppression, which resemble the multiple chemical sensitivity syndromes [13-16]. Cypermethrin is a chemical which is genotoxic in the spleen mouse and bone marrow cells and carcinogenic [15-17].

Several studies have been published on carbamates and pyrethroid pesticide residues globally. Some of these studies include the determination of pyrethroid insecticide and sediment toxicity in urban creeks from California and Tennessee by Anweg et al., [9]. A reassessment of the neurotoxicity of pyrethroid insecticides had also been reported by Ray et al., [10] .Other studies on carbamate pesticide pollution include: Analysis of carbamate and phenyl urea pesticide residues in fruit juices by solid-phase micro extraction and liquid chromatography-mass spectrometry by Paiga et al., [7]. Analysis of carbamate and phenyl urea pesticide residues in fruit juices by solid-phase microextraction and liquid chromatography-mass spectrometry was also reported bySagratini et al., [23]. Other studies includeexaminination of pyrethroids, carbamates and neonicotenoids in fish, water and sediments from the Indus River for potential health risks Jabeen et al., [31].
Previous studies on pesticide pollution in Nigeria focused mainly on organochlorine and organophosphate pesticide residues. There is little information on the occurrence of carbamate and pyrethroid residues in Owena river basin, Ondo state, Nigeria. River Owena is located along the major coca producing area of Ondo State where carbamates and pyrethroid pesticides are used to control cocoa pests in farms at the river basin. The residues discharged through runoff into the Owenariver. This river is a source of drinking water to the people of Ondo Central Senatorial district. However, there is no much information on the effects of these pesticide residues on the treated water from the nearby Ondo State Water Works at the river basin. The specific objectives of this study are to: (i) investigate the presence and the type of pesticide residues in the cocoa soil and monitor their seepage into Owena river water and sediments through runoff and other sources; (ii) assess the presence of the pesticide residues in the raw and treated water from the water works; and (iii) develop a baseline data on the occurrence and levels of pesticides residues in river Owena raw and treated water and hence the environmental and health implication.

\section{MATERIALS AND METHODS \\ Description of Study Area}

The study area is the Owena River basin which is located on geographical coordinates $7^{0} 15^{\prime}$ and $5^{0} 5^{\prime} \mathrm{E}$ in the Ondo East (Local Government Area) of Ondo State, Nigeria.

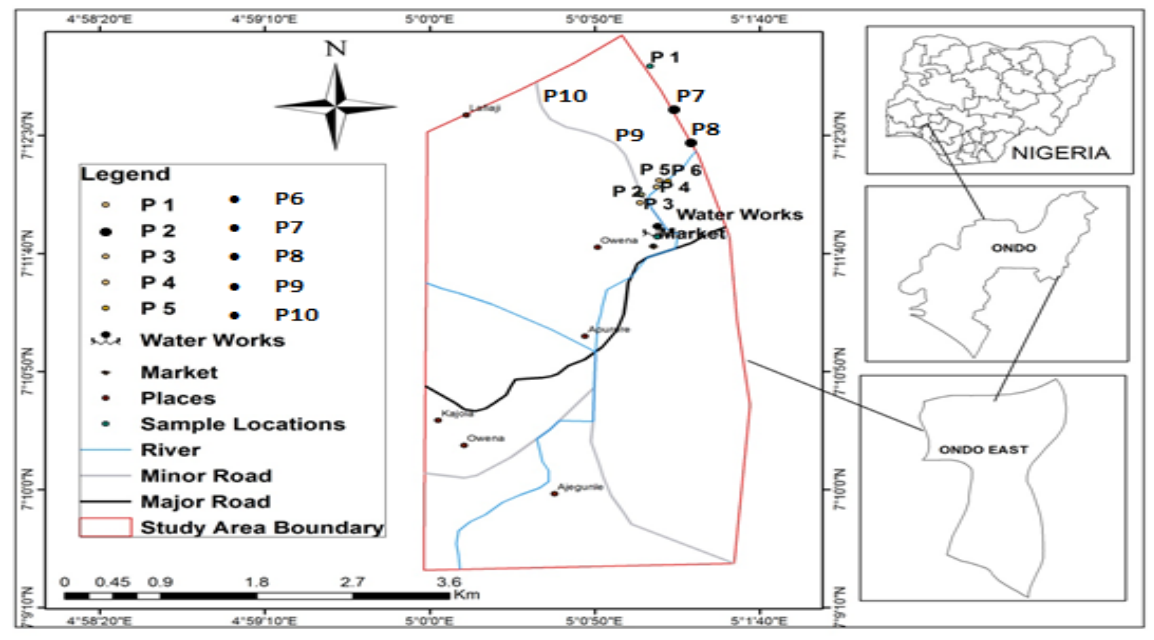

Fig-1: Map of the study area showing the Location of Owena River Basin in Ondo State, Nigeria

\section{Collection, Handling, Preservation and Storage of Samples}

Twenty soil samples were collected under each cocoa plant canopy from the depth of $0-5 \mathrm{~cm}$ using a soil auger to form a composite sample. The collected composite samples was ten and they were kept in a polythene bag. The composite soil samples were dried at room temperature and sieved through $2 \mathrm{~mm}$ stainless sieve.

Twenty composite sediment samples were collected from $0-5 \mathrm{~cm}$ depth from the same spot in which the water samples were collected. The sediment samples were taken from the bottom surface of the river. The samples were wrapped up in aluminum foils, 
air dried and sieved through $2.0 \mathrm{~mm}$ stainless steel sieve [19-20].

Twenty water samples comprising river raw water, water under treatment and treated (drinking water) using pretreated Winchester glass bottles with Teflon lined screw caps using the method by Akinnifesi et al., [19]. Sampling bottles were rinsed three times with the sample river raw water and then filled to the brim. The bottle stopper was removed with one hand and with another hand the bottle was held at its base and inserted by the mouth downward below the surface of the water. River water from the treatment plant were also collected in Winchester bottles from the reservoir of the water treatment plant by rinsing the bottle thrice with raw water before inserting it into the water surface of the reservoir. The treated (drinking) water from the Water Works was collected directly from the tap water around the water processing plant. About $10 \mathrm{~mL}$ of HPLC grade extracting solvent (hexane) was added to the water samples immediately after the collection to start the extraction. Analytical grade concentrated $\mathrm{HNO}_{3}$ was also added to prevent microbial degradation [24-28]. The water samples were stored at $4^{\circ} \mathrm{C}$ in the laboratory prior to extraction.

\section{Extraction of Pesticide Residues from the Water Samples}

Pesticides extraction from the soil and sediment samples was performed with method 3550 as described by US EPA [24]. A Super Scientific$100005(50 \mathrm{~W}, 45 \mathrm{KHz})$ ultrasonic bath was used. Ten grams of the soil or sediment sample was weighed into a $50 \mathrm{~mL}$ glass beaker containing $50 \mathrm{~g}$ of $\mathrm{Na}_{2} \mathrm{SO}_{4}$, mixed and then covered with aluminum foil. About $20 \mathrm{~mL}$ of the extracting solvent mixture (acetone/hexane 1:1v/v) were used. The temperature of the ultrasonic bath was set at $25^{\circ} \mathrm{C}$ and the extraction time was set at 30 minutes. The glass beaker was placed on the ultrasonic bath and a sufficient water quantity was filled into the bath in order to cover three quarters of the beaker (the water in the bath was above the volume of the solvent in the beaker). This condition was maintained constant during all the experiments. The extraction was carried out in triplicates and the extracts were combined and filtered prior to the cleanup step.

\section{Extraction of Pesticide Residues from the Water Samples}

Pesticide residues extraction from river, raw and treated water samples were carried out with EPA method 3510c [24]. Sixty $\mathrm{mL}$ of hexane were introduced into a separating funnel containing $1000 \mathrm{~mL}$ of the water samples and $5 \mathrm{~g}$ of $\mathrm{NaCl}$ for phase separation and shaken vigorously for about 30 minutes. The samples were allowed to settle to ensure separation of the phases. After separation, the organic layer was filtered into a $250 \mathrm{ml}$ amber glass bottles that has been pre-washed with hexane and $5 \mathrm{~g} \mathrm{Na}_{2} \mathrm{SO}_{4}$ added to remove any residual water in the organic phase. The extracts were filtered and extractions were repeated thrice using a $60 \mathrm{~mL}$ portion of hexane and later combined for cleanup.

\section{Clean-Up of the Extracts}

Extracts from each samples were concentrated to $20 \mathrm{~mL}$ with a gentle $\mathrm{N}_{2}$ current and then added with $10 \mathrm{ml}$ of $0.1 \mathrm{~mL} \mathrm{Na}_{2} \mathrm{CO}_{3}$ solution and shaken for 5 minutes. The free fatty acids containing aqueous phase was discarded [19]. Sulphur, usually associated with sediment samples was removed by adding $2 \mathrm{~g}$ of activated powdered copper to the extracts and shaken for 5 minutes [9]. The organic phase was separated by chromatographic cleanup technique in which $10 \mathrm{~g}$ of alumina was placed in the chromatographic column. The column was tapped to settle the alumina and $2 \mathrm{~g}$ of anhydrous $\mathrm{Na}_{2} \mathrm{SO}_{4}$ was added to the top of the column. The column was then pre- eluted with $40 \mathrm{~mL}$ of hexane at elution rate of $2 \mathrm{~mL} / \mathrm{min}$. Twenty $\mathrm{mL}$ sample extracts were quantitatively transferred into the column using additional $2 \mathrm{mLof}$ hexane to complete the transfer and then the column was finally eluted with $140 \mathrm{~mL}$ ethyl ether/hexane $(1 / 4 \mathrm{v} / \mathrm{v})$. The eluate was concentrated to $2 \mathrm{~mL}$ with a gentle stream of $\mathrm{N}_{2}$ current and transferred into amber glass vials for GC/MS analysis [29-32].

\section{GC-MS Analysis}

The cleaned extracts were analyzed on a gas chromatograph in triplicates from Agilent USA hyphenated to a mass spectrophotometer (5975C) with triple axis detector equipped with an auto injector .Helium was used as carrier gas. All the chromatographic separations were performed on a capillary column having specification: lenght; 30m, internal diameter $(0.2 \mu \mathrm{m})$ thickness; $250 \mu \mathrm{m}$, treated with phenyl methyl siloxane. Other GC-MS conditions are ion source temperature (EI) $250^{\circ} \mathrm{C}$, interface temperature; $230^{\circ} \mathrm{C}$,pressure; 16.2 as well as $1 \mu \mathrm{L}$ injector in split mode with split ratio 1:50 with injection temperature of $300^{\circ} \mathrm{C}$. The column temperature started with $35^{\circ} \mathrm{C}$ for 5 minutes and changed to $150^{\circ} \mathrm{C}$ at the rate of $4^{\circ} \mathrm{C} / \mathrm{min}$. The temperature was raised to $250^{\circ} \mathrm{C}$ at the rate of $20^{\circ} \mathrm{C} / \mathrm{min}$. and held for 5 minutes with solvent delay of 5 minutes. The total elution was 47.5 minutes. The compounds were identified by comparing the mass spectra obtained with those of the standard mass spectra from NIST library [33-37]

\section{Quantification}

Cypermethrin was used as the external standard. Average calibration factor (CF) was used for the calculation since the relative standard deviation of the calibration standards at five different concentrations was $<20 \%$. Hence, the response of the detector to analyte concentration was assumed to be linear and the mean calibration factor was used for quantiation. A detailed description of this method is given by US Environmental Protection Agency method 8081B [38].

Calculation of the concentrations of fish samples Concentration $(\mu \mathrm{g} / \mathrm{g})=(\mathrm{Ax})(\mathrm{Vt})(\mathrm{D}) /(\mathrm{CF})(\mathrm{Vi})(\mathrm{Ws})$ 
Where

$\mathrm{Ax}=$ Area (or height) of the peak for the analyte in the sample.

$\mathrm{Vt}=$ Total volume of the concentrated extract $(\mu \mathrm{L})$.

$\mathrm{D}=$ Dilution factor is 1 since the sample or extracts were not diluted prior to analysis.

$\mathrm{CF}=$ Mean calibration factor from the initial calibration $\mathrm{Vi}=$ Volume of the extract injected $(\mu \mathrm{L})$.

\section{Quality assurance/quality control}

Background phythalate ester contamination were eliminated by exhaustive cleanup of reagents solvents and thoroughly washing of glasswares with detergent and rinsing with triply distilled water and running of field and lab blanks.

\section{RESULTS AND DISCUSSION \\ Carbamate Pesticide Residues in Soil Samples}

The mean concentrations of carbamate pesticide residues in the cocoa-producing soil samples is presented in Tables 1 and 2 for dry and wet seasons respectively. These values ranged from 0.69 to $1.38 \mu \mathrm{g} / \mathrm{g}$ and $0.70-1.79 \mu \mathrm{g} / \mathrm{g}$ for dry and wet seasons respectively. Their total mean concentration values were $1.01 \pm 0.29 \mu \mathrm{g} / \mathrm{g}$ and $0.78 \pm 0.05 \mu \mathrm{g} / \mathrm{g}$ for dry and wet seasons respectively. Carbaryl, carbofuran and isoprocarb were the frequently occurring carbamate pesticide residues in the soil samples in dry seasons. However, only carbaryl and isoprocarb were detected in the raining season. Their mean level individually were: $1.03 \pm 0.61 \mu \mathrm{g} / \mathrm{g}, 0.71 \pm 0.350 \mu \mathrm{g} / \mathrm{g}$ and $1.26 \pm 1.39 \mu \mathrm{g} / \mathrm{g}$ respectively in dry season for Carbaryl, carbofuran and isoprocarb respectively. The wet season values were: $0.82 \pm 0.05 \mu \mathrm{g} / \mathrm{g}$ and $0.73 \pm 0.04 \mu \mathrm{g} / \mathrm{g}$ for isoprocarb and carbaryl respectively. The lower frequency of occurrence of these contaminants in the raining season could be due to dilution. Their distribution trend as shown in Table-1 in dry seasons is: isoprocarb $>$ carbaryl $>$ carbofuran while the trend in raining season is isoprocarb>carbary (Table-2). Their presence indicated that pesticides containing carbamates were also used in the study area but not as frequently as the organohlorine, organophosphate and pyrthroid insecticides. Isoprocarb had the highest level of these contaminants in the soil samples in both seasons. This could be that the farmers were using the unapproved chemicals ignorantly under different trade names for pesticide control. Isoprocarb was a previously approved insecticide for cocoa pest control in Nigeria [22]. This study reported a higher mean concentration of $1.02 \pm 0.29 \mu \mathrm{g} / \mathrm{g}$ and $0.78 \pm 0.05 \mu \mathrm{g} / \mathrm{g}$ (Tables 1 and 2) when compared to the $0.014 \mathrm{mg} \mathrm{kg}^{-1}$ reported in a previous study Wabel et al., [24] in a study on the pesticide (carbamate) residues in soil samples collected from 15 regions around Saudi Arabia. However, the level of contamination in dry season was higher than that of the raining season (Figure-2). This could be as a result of leaching from the surface of the soil during wet season. However, the levels of carbamate pesticide residues in the two seasons were still within the range of $0.1-8 \mu \mathrm{g} / \mathrm{g}$ MRL for pesticide pollution in agricultural soil by FAO [37].This indicated that carbamate pesticide pollution level in the study area is still within acceptable international limit.

Table-1: Mean Concentration of Carbamate Pesticide Residues in Cocoa-Producing Soil, Sediment, Surface Water, Water Under Treatment and Treated Water Samples During Dry Season

\begin{tabular}{|c|c|c|c|c|c|c|c|c|c|c|}
\hline Pesticide & $\begin{array}{l}\text { Soil } \\
(\mu \mathrm{g} / \mathrm{g})\end{array}$ & & $\begin{array}{l}\text { Sediment } \\
(\mu \mathrm{g} / \mathrm{g})\end{array}$ & & $\begin{array}{l}\text { Surface } \\
\text { water } \\
(\mu \mathrm{g} / \mathrm{L})\end{array}$ & & $\begin{array}{l}\text { Water } \\
\text { under } \\
\text { treatment } \\
(\mu \mathrm{g} / \mathrm{L})\end{array}$ & & $\begin{array}{l}\text { Treated } \\
\text { water } \\
(\mu \mathrm{g} / \mathrm{L})\end{array}$ & \\
\hline & mean \pm sd & Range & mean \pm sd & Range & mean \pm sd & Range & mean \pm sd & Range & mean \pm sd & Range \\
\hline Aldicarb & ND & - & ND & - & ND & - & ND & - & ND & - \\
\hline Fenoxycarb & ND & - & ND & - & ND & - & ND & - & ND & - \\
\hline Carbaryl & $1.03 \pm 0.61$ & $\begin{array}{l}0.99- \\
1.19\end{array}$ & $4.70 \pm 1.48$ & $\begin{array}{l}4.68- \\
4.88\end{array}$ & ND & - & ND & - & ND & - \\
\hline Methomyl & ND & - & ND & - & ND & - & ND & - & ND & - \\
\hline Carbofuran & $0.71 \pm 0.35$ & $\begin{array}{l}0.69- \\
0.74\end{array}$ & $1.88 \pm 0.47$ & $\begin{array}{l}1.80- \\
1.96\end{array}$ & ND & - & ND & - & ND & - \\
\hline Isoprocarb & $1.28 \pm 1.84$ & $\begin{array}{l}1.26- \\
1.38\end{array}$ & $0.76 \pm 0.53$ & $\begin{array}{l}0.70- \\
0.84\end{array}$ & ND & - & ND & - & ND & - \\
\hline Fenobucarb & ND & - & ND & - & ND & - & ND & - & ND & - \\
\hline Oxamyl & ND & - & ND & - & ND & - & ND & - & ND & - \\
\hline$\sum \mathrm{CM}$ & 3.02 & - & 7.34 & - & ND & - & ND & - & ND & - \\
\hline Total Mean & 1.01 & - & 2.45 & - & - & - & - & - & - & - \\
\hline SD & 0.29 & - & 2.38 & - & - & - & - & - & - & - \\
\hline $\mathrm{CV}$ & 28.71 & - & 82.25 & - & - & - & - & - & - & - \\
\hline ANOVA & $\mathrm{P} \geq 0.05$ & - & $\mathrm{P} \geq 0.05$ & - & - & - & - & - & - & - \\
\hline Remarks & $\overline{\mathrm{NS}}$ & - & $\overline{\mathrm{NS}}$ & - & - & - & - & - & - & - \\
\hline
\end{tabular}


$\Sigma \mathrm{CM}=$ Total carbamate pesticides residues; $\mathrm{ND}=$ Not detected; $\mathrm{sd}=$ Standard deviation; ANOVA=Analysis of variance; $\mathrm{ND}=$ Not detected.

Table-2: Mean Concentration of Carbamate Pesticide Residues in Cocoa-Producing Soil, Sediment, Surface

\begin{tabular}{|c|c|c|c|c|c|c|c|c|c|c|}
\hline \multicolumn{11}{|c|}{ Water Samples During Wet Season } \\
\hline Pesticide & $\begin{array}{l}\text { Soil } \\
(\mu \mathrm{g} / \mathrm{g})\end{array}$ & & $\begin{array}{l}\text { Sediment } \\
(\mu \mathrm{g} / \mathrm{g})\end{array}$ & & $\begin{array}{l}\text { Surface } \\
\text { water } \\
(\mu \mathrm{g} / \mathrm{L})\end{array}$ & & $\begin{array}{l}\text { Water } \\
\text { under } \\
\text { treatment } \\
(\mu \mathrm{g} / \mathrm{L})\end{array}$ & & $\begin{array}{l}\text { Treated } \\
\text { water } \\
(\mu \mathrm{g} / \mathrm{L})\end{array}$ & \\
\hline & mean \pm sd & Range & mean \pm sd & Range & mean \pm sd & Range & mean \pm sd & Range & mean \pm sd & Range \\
\hline Aldicarb & ND & - & ND & - & ND & - & NS & - & NS & - \\
\hline Fenoxycarb & ND & - & ND & - & ND & - & NS & - & NS & - \\
\hline Carbaryl & $0.82 \pm 0.05$ & $\begin{array}{l}0.78- \\
0.91\end{array}$ & $0.91 \pm 0.08$ & $\begin{array}{l}0.88- \\
1.08 \\
\end{array}$ & ND & - & NS & - & NS & - \\
\hline Methomyl & ND & - & ND & - & ND & - & NS & - & NS & - \\
\hline Carbofuran & ND & - & ND & - & ND & - & NS & - & NS & - \\
\hline Isoprocarb & $0.73 \pm 0.04$ & $\begin{array}{l}0.70- \\
1.79\end{array}$ & $0.61 \pm 0.05$ & $\begin{array}{l}0.59- \\
0.71\end{array}$ & $\mathrm{ND}$ & - & NS & - & NS & - \\
\hline Fenobucarb & ND & - & ND & - & ND & - & NS & - & NS & - \\
\hline Oxamyl & ND & - & ND & - & ND & - & NS & - & $\mathrm{NS}$ & - \\
\hline$\sum \mathrm{CM}$ & 1.55 & - & 1.52 & - & ND & - & NS & - & NS & - \\
\hline Total Mean & 0.78 & - & 0.76 & - & - & - & - & - & - & - \\
\hline $\mathrm{SD}$ & 0.05 & - & 0.15 & - & - & - & - & - & - & - \\
\hline $\mathrm{CV}$ & 6.41 & - & 19.74 & - & - & - & - & - & - & - \\
\hline ANOVA & $P \geq 0.05$ & & $P \geq 0.05$ & - & - & - & - & - & - & - \\
\hline Remarks & NS & & NS & & & & & & & \\
\hline
\end{tabular}

$\Sigma \mathrm{CM}=$ Total carbamate pesticides residues; $\mathrm{ND}=$ Not detected; $\mathrm{sd}=$ Standard deviation; ANOVA=Analysis of variance; $\mathrm{ND}=$ Not detected; $\mathrm{NS}=$ No sample

\section{Carbamate Pesticide Residues in Sediment Samples}

The mean concentration of carbamate pesticide residues from the sediment samples is contained in Tables 3 and 4 . These values ranged from 0.70 to $4.88 \mu \mathrm{g} / \mathrm{g}$ and $0.59-1.08 \mu \mathrm{g} / \mathrm{g}$ respectively for dry and wet seasons. Their total mean concentration values were $2.45 \pm 2.38 \mu \mathrm{g} / \mathrm{g}$ and $0.76 \pm 0.15 \mu \mathrm{g} / \mathrm{g}$ for dry and wet seasons respectively. Sediments accumulate these chemicals as they are washed into river Owena. The higher specific gravities of these pollutants could be attributed to their accumulation of in the sediments. The mean level of Carbaryl, carbofuran and isoprocarb were $4.70 \pm 1.484 \mu \mathrm{g} / \mathrm{g}, \quad 1.88 \pm 0.47 \mu \mathrm{g} / \mathrm{g}$ and $0.77 \pm 0.53 \mu \mathrm{g} / \mathrm{g}$ respectively.Their low concentrations could be attributed to their molecular structures which are somewhat similar to the structures of some natural organics which degrade naturally without polluting the environment [23].The dry season trend of contamination in the sediment as shown in Table 1 is carbaryl $>$ carbofuran $>$ isoprocarbwhilee their distribution in wet seasons is: carbaryl>isoprocarb (Table-2). The pollution level of these contaminants is higher in dry season than wet period (Figure-2). These contaminants tend to sink into the sediments since they are heavier than water. Their non - polar nature due to their low dielectric constants could also attest to that behavior. Thus, they accumulate easily on the sediments than water $[17,21,30]$. Interestingly the carbamate insecticide residues found in the soil matricewere also found in the sediment in both seasons. However, carbamate pesticide residues were not found in the water samples due to their low persistence and easy degradability. They could have been degraded by hydrolysis in water. They have very short half live as they degrade within one to two days depending on their environment $[9-12,23,25]$. The $1.88 \pm 0.470 \mu \mathrm{g} / \mathrm{g}$ (Table-1) observed in this study for carbamates (carbofuran), in sediment is higher than 0.069$0.081 \mu \mathrm{g} / \mathrm{g}$ value for carbofuran in sediments as reported by Jabeen et al., [40] in a study on the examination of pyrethroids, carbamates and neonicotenoids in fish, water and sediments from the Indus River for potential health risks because carbamates with carbaryl active ingredients could frequently be used in the study area. The higher level of carbaryl in the sediment than the soil matrix could be due to their introduction through other sources such as fishing in the river. My interaction with some of the farmers and fishermen at the river basin during the sampling revealed that some of these fishermen were using some of these chemicals in killing fishes by direct application into the river. This study revealed that the accumulation of carbamate pesticide residues in the sediment is more than the major source of pollution (soil) suggesting that the carbamate pollution of the water body is from different sources. This might include the direct application of the pesticides to the water by fishermen. The occurrence level of thecarbamate pesticide residues in all the investigated matrices are sediment $>$ soil (Figure-2). 


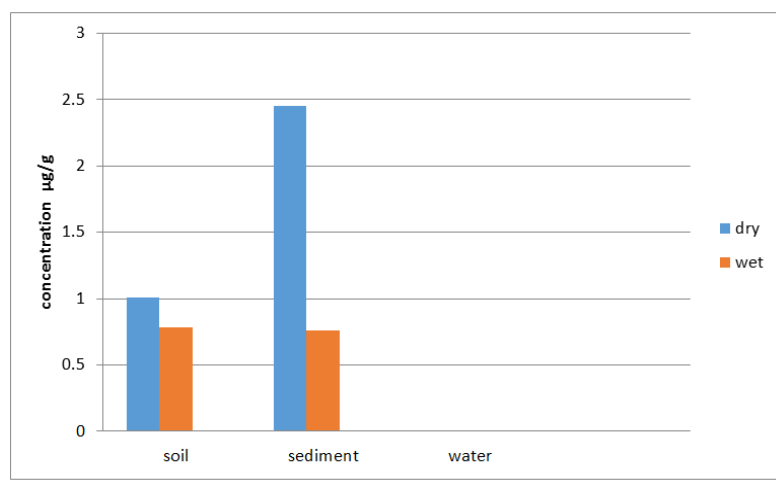

Fig-2: Level of occurrence of compounds of carbamate pesticide residues in cocoa-producing soil, sediment and surface water during dry and wet seasons

\section{Pyrethroid Pesticide Residues in Soil Samples}

The mean concentration of pyrethroid pesticide residues from the cocoa-producing soil samples is shown in Tables 3 and 4. These values ranged from 0.50 to $4.19 \mu \mathrm{g} / \mathrm{g}$ and $0.32-1.29 \mu \mathrm{g} / \mathrm{g}$ respectively for dry and wet seasons. Their total mean concentration values were $2.61 \pm 1.87 \mu \mathrm{g} / \mathrm{g}$ and $0.70 \pm 0.25 \mu \mathrm{g} / \mathrm{g}$ for dry and wet seasons respectively. Their distribution trend as shown in indicates that cypermethin had the highest frequency of occurrence in the studied matrices. Hence, it is probably the most commonly used insecticide in the study area. This observation was not surprising since pesticides containing its active ingredients are openly sold in major markets in Nigeria under different trade names. Deltamethrin with the trade name of Proteus $1 \mathrm{O}-\mathrm{TE}$ is a currently approved pesticide for cocoa farms in Nigeria [22]. FosuMensah et al., [12] reported the presence of cypermethrin $(0.04 \mathrm{mg} / \mathrm{kg})$ and deltamethrin $(0.06 \mathrm{mg} / \mathrm{kg})$ in soils and drinking water from cocoa farms in Dorma West District of Ghana which were higher than $4.21 \pm 2.74 \mu \mathrm{g} / \mathrm{g}$ and $0.56 \pm$ $0.010 \mu \mathrm{g} / \mathrm{g}$ (Table-3) reported in this study for cypermethrin and deltamethrin respectively in dry season. Pesticides residues in soils are toxic to plants and their products $[5,14]$. These pollutants get into the food chain through runoff, leaching and other source [9] [18] [20] .Cypermethrin concentration range of 0.012$0.205 \mathrm{mg} \mathrm{kg}-1$ reported in a study by Wabel, et al., [24] on pesticide residues in Saudi Arabia soil indicated higher contamination level than the $4.21 \pm 2.74 \mu \mathrm{g} / \mathrm{g}$ reported in this study. This could be as a result of the heavy use of these chemicals in Saudi Arabia than the study area. The seasonal contamination trend in the soil as shown in Table 3 and Table 4 is cypermethrin>cispermethrin>deltamethrinfor both seasons. The mean level of pyrethroid in this study was lower than the $0.05 \mathrm{mg} / \mathrm{kg}$ US maximum residue limit for slightly polluted soil, and $8 \mu \mathrm{g} / \mathrm{g}$ limit by the Food Agricultural Organization of United Nations. Dry season contamination was higher than wet season (Figure-3).

Table-3: Mean Concentration of Pyrethroid Pesticide Residues in Cocoa-Producing Soil, Sediment, Surface Water, Water under Treatment and Treated Water Samples During Dry Season

\begin{tabular}{|c|c|c|c|c|c|c|c|c|c|c|}
\hline Pesticide & $\begin{array}{l}\text { Soil } \\
(\mu \mathrm{g} / \mathrm{g})\end{array}$ & & $\begin{array}{l}\text { Sediment } \\
(\mu \mathrm{g} / \mathrm{g})\end{array}$ & & $\begin{array}{l}\text { Surface } \\
\text { water } \\
(\mu \mathrm{g} / \mathrm{L})\end{array}$ & & $\begin{array}{l}\text { Water } \\
\text { under } \\
\text { treatment } \\
(\mu \mathrm{g} / \mathrm{L})\end{array}$ & & $\begin{array}{l}\text { Treated } \\
\text { water } \\
(\mu \mathrm{g} / \mathrm{L})\end{array}$ & \\
\hline & mean \pm sd & Range & mean \pm sd & Range & mean \pm sd & Range & mean \pm sd & Range & $\begin{array}{l}\text { mean } \pm \\
\text { sd }\end{array}$ & Range \\
\hline Bifenthrin & ND & - & ND & - & ND & - & ND & - & ND & - \\
\hline $\begin{array}{l}\text { Cis- } \\
\text { permethrin }\end{array}$ & $3.06 \pm 0.93$ & $\begin{array}{l}2.98- \\
3.16 \\
\end{array}$ & $0.44 \pm 0.08$ & $\begin{array}{l}0.40- \\
0.51 \\
\end{array}$ & ND & - & ND & - & ND & - \\
\hline Cypermethrin & $4.21 \pm 2.74$ & $\begin{array}{l}4.19- \\
4.31\end{array}$ & $2.73 \pm 2.28$ & $\begin{array}{l}2.68- \\
2.84\end{array}$ & 0.01 & $\begin{array}{l}0.00- \\
0.02\end{array}$ & 0.01 & $\begin{array}{l}0.00- \\
0.01\end{array}$ & ND & - \\
\hline $\begin{array}{l}\text { Trans- } \\
\text { permethrin }\end{array}$ & ND & - & ND & - & ND & - & ND & - & ND & - \\
\hline Talomethrin & ND & ND & ND & ND & ND & - & ND & - & ND & - \\
\hline Deltamethrin & $0.56 \pm 0.10$ & $\begin{array}{l}0.50- \\
0.65\end{array}$ & $0.43 \pm 0.09$ & $\begin{array}{l}0.41- \\
0.52 \\
\end{array}$ & ND & - & ND & - & ND & - \\
\hline Resmethrin & ND & - & ND & - & ND & - & ND & - & ND & - \\
\hline Fenpropathrin & ND & - & ND & - & ND & - & ND & - & ND & - \\
\hline$\sum \mathrm{PP}$ & 7.83 & - & 3.60 & - & ND & - & ND & - & ND & - \\
\hline Total Mean & 2.61 & - & 1.20 & - & $<0.01$ & - & $<0.01$ & - & ND & - \\
\hline SD & 1.87 & - & 1.33 & - & - & - & - & - & - & - \\
\hline $\mathrm{CV}$ & 71.65 & - & 110.83 & - & - & - & - & - & - & - \\
\hline ANOVA & $\mathrm{P} \geq 0.05$ & - & $\mathrm{P} \geq 0.05$ & - & - & - & - & - & - & - \\
\hline Remarks & $\mathrm{NS}$ & - & $\mathrm{NS}$ & - & - & - & - & - & - & - \\
\hline
\end{tabular}

$\sum \mathrm{PP}=$ Total Pyrethroid pesticides residues; $\mathrm{ND}=$ Not detected; $\mathrm{sd}=$ Standard deviation; ANOVA=Analysis of variance; $\mathrm{ND}=$ Not detected 
Table-4: Mean Concentration of Pyrethroid Pesticide Residues in Cocoa-Producing Soil, Sediment, Surface Water, Water under Treatment and Treated Water Samples during Wet Season

\begin{tabular}{|c|c|c|c|c|c|c|c|c|c|c|}
\hline Pesticide & $\begin{array}{l}\text { Soil } \\
(\mu \mathrm{g} / \mathrm{g})\end{array}$ & & $\begin{array}{l}\text { Sediment } \\
(\mu \mathrm{g} / \mathrm{g})\end{array}$ & & $\begin{array}{l}\text { Surface } \\
\text { water } \\
(\mu \mathrm{g} / \mathrm{L})\end{array}$ & & $\begin{array}{l}\text { Water } \\
\text { under } \\
\text { treatment } \\
(\mu \mathrm{g} / \mathrm{L})\end{array}$ & & $\begin{array}{l}\text { Treated } \\
\text { water } \\
(\mu \mathrm{g} / \mathrm{L})\end{array}$ & \\
\hline & mean \pm sd & Range & mean \pm sd & Range & $\begin{array}{l}\text { mean } \pm \\
\text { sd }\end{array}$ & Range & mean \pm sd & Range & mean \pm sd & Range \\
\hline Bifenthrin & ND & - & ND & - & ND & - & NS & - & NS & - \\
\hline $\begin{array}{l}\text { Cis- } \\
\text { permethrin }\end{array}$ & $0.79 \pm 0.05$ & $\begin{array}{l}0.74- \\
0.85\end{array}$ & $0.27 \pm 0.03$ & $\begin{array}{l}0.20- \\
0.34\end{array}$ & ND & - & NS & - & NS & - \\
\hline Cypermethrin & $0.96 \pm 0.03$ & $\begin{array}{l}0.92- \\
1.29\end{array}$ & $0.77 \pm 0.02$ & $\begin{array}{l}0.72- \\
0.85\end{array}$ & ND & - & NS & - & NS & - \\
\hline $\begin{array}{l}\text { Trans- } \\
\text { permethrin }\end{array}$ & ND & - & ND & - & ND & - & NS & - & NS & - \\
\hline Talomethrin & ND & - & ND & - & ND & - & NS & - & NS & - \\
\hline Deltamethrin & $0.36 \pm 0.03$ & $\begin{array}{l}0.32- \\
0.40\end{array}$ & $0.22 \pm 0.3$ & $\begin{array}{l}0.19- \\
0.28\end{array}$ & ND & - & NS & - & NS & - \\
\hline Resmethrin & ND & - & ND & - & ND & - & NS & - & $\mathrm{NS}$ & - \\
\hline Fenpropathrin & ND & - & ND & - & ND & - & NS & - & NS & - \\
\hline$\sum \mathrm{PP}$ & 2.11 & - & 1.26 & - & ND & - & NS & - & NS & - \\
\hline Total Mean & 0.70 & - & 0.42 & - & ND & - & NS & - & NS & - \\
\hline SD & 0.25 & - & 0.25 & - & - & - & - & - & - & - \\
\hline $\mathrm{CV}$ & 35.71 & - & 59.52 & - & - & - & - & - & - & - \\
\hline ANOVA & $\mathrm{P} \geq 0.05$ & - & $\mathrm{P} \geq 0.05$ & - & - & - & - & - & - & - \\
\hline Remarks & $\mathrm{NS}$ & - & NS & - & - & - & - & - & - & - \\
\hline
\end{tabular}

$\sum \mathrm{PP}=$ Total Pyrethroid pesticides residues; $\mathrm{ND}=$ Not detected; $\mathrm{sd}=$ Standard deviation; $\mathrm{ANOVA}=$ Analysis of variance $; \mathrm{ND}=\mathrm{Not}$ detected; NS = No sample.

\section{Pyrethroid Pesticide Residues in Sediment Samples}

Tables 3 and 4 contain the concentration of pyrehroid pesticide residues Sediment samples. These values ranged from 0.40 to $2.84 \mu \mathrm{g} / \mathrm{g}$ and 0.19 to $0.85 \mu \mathrm{g} / \mathrm{g}$ respectively for dry and wet seasons. Their total mean concentration values were $1.20 \pm 1.33 \mu \mathrm{g} / \mathrm{g}$ and $0.42 \pm 0.25 \mu \mathrm{g} / \mathrm{g}$ for dry and wet seasons respectively. The frequently occurring pyrethroids in both seasons in the sediment were cypermethrin, cispermethrin and deltamethrin. Pyrethroids are easily biodegradable in the environment [12]. Their presence in the sediments could be due to recent usage. Sediments are heterogeneous and the uptake of these pollutants by benthic organisms is at different concentrations. In comparism to $1.20 \pm 1.33 \mu \mathrm{g} / \mathrm{g}$ and $0.42 \pm 0.25 \mu \mathrm{g} / \mathrm{g}$ mean level obtained in both seasons from this study. Akan et al.,[4] reported a higher concentration of pyrethroid $(11.93 \pm 2.13 \mu \mathrm{g} / \mathrm{g})$ in a study on pyrethroid determination in sediments of River Benue in Vinikilang, Yola, and Adamawa State. Jabeen et al., [40] reported mean concentration of 0.214 $0.318 \mu \mathrm{g} / \mathrm{g}$ for deltamathrin and $0.183-0.197 \mu \mathrm{g} / \mathrm{g}$ for cypermethrin in a study of the examination of pyrethroids, carbamatesand neonicotenoids in fish, water and sediments from the Indus River for potential health risks. However, the mean levels of $0.43 \pm 0.09$ $\mu \mathrm{g} / \mathrm{g}$ and $2.73 \pm 2.28 \mu \mathrm{g} / \mathrm{g}$ in dry season observed in this study for deltamathrin andcypermethrin were higher than the reported values in the study by Jabeen et al., [40]. The distribution trend of the pyrethroids in the sediments as shown in Table 3 and Table-4 is cypermethrin>cis- cypermethrin $>$ deltamathrin in both seasons. However, dry season pollution was higher than the wet season (Figure-3). Interestingly, all Pyrethroids pesticides detected in the soil samples were also found in the sediments. This could be a proof that pesticides with pyrethroids active ingredients are frequently used in cocoa farms in the study area and they are washed into the Owenariver. Cypermethrin is a currently approved Pesticide for cocoa farming in Nigeria [22] The order of contamination as shown in Figure 3 in the investigated matrices are soil > sediment > surface water. The mean concentrations of some of the carbamate and pyrethroid residues in the sediment samples were higher than $0.3 \mu \mathrm{g} / \mathrm{g}$ EU maximum residue limit but less than $2 \mu \mathrm{g} / \mathrm{g}$ allowable level by FAO-WHO. 


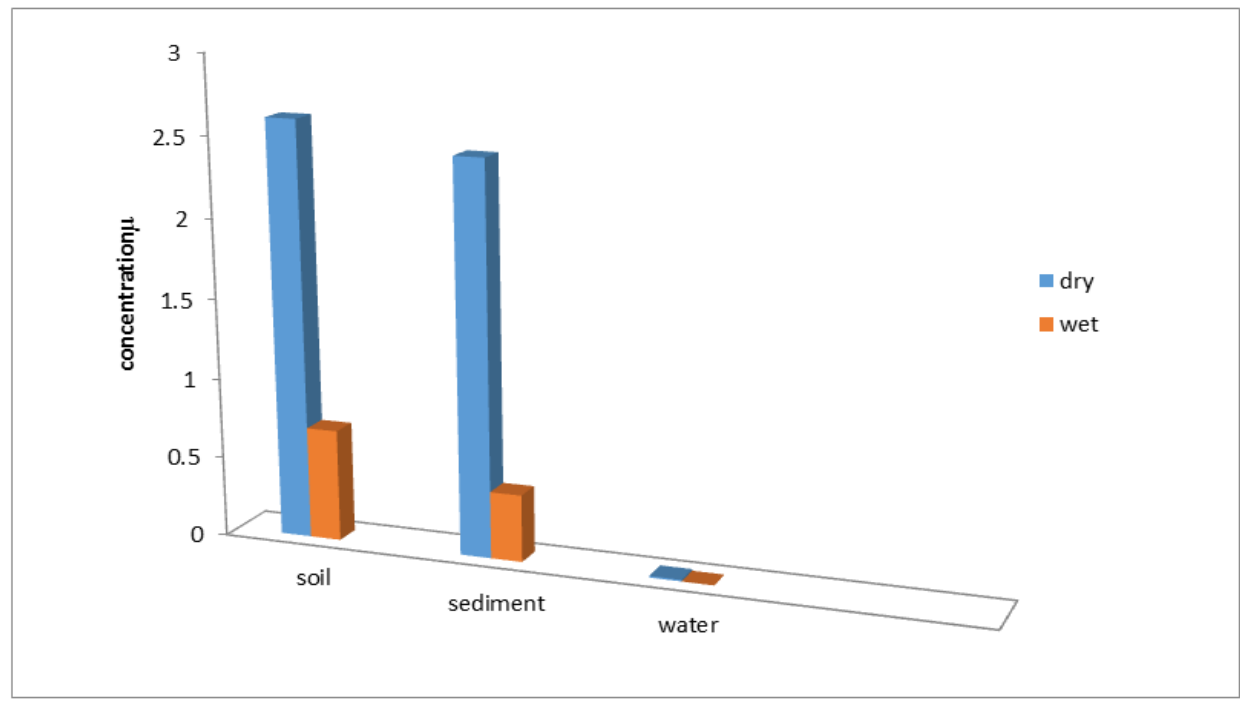

Fig-3: Levels of compounds of pyrethroid pesticide residue in cocoa-producing soil, sediment and surface water during dry and wet seasons

Note: The soil, sediment and fish samples were expressed in $\mu \mathrm{g} / \mathrm{g}$ while the surface water samples were expressed in $\mu \mathrm{g} / \mathrm{L}$

\section{Pyrethroid Pesticide Residues in Water Samples}

Tables 3 and 4 showed the values for the mean concentrations of cypermethrin, the only detected pyrethroid pesticide residues in the water samples in dry season which ranged from $0.00-0.02 \mu \mathrm{g} / \mathrm{L}, 0.00$ $0.01 \mu \mathrm{g} / \mathrm{L}$ for surface water and water under treatment respectively for dry season. Their mean concentration values were $<0.01 \mu \mathrm{g} / \mathrm{L}$. However, these pollutants were not detected in the treated water samples in dry season. There was no contaminant found in the surface water samples during the wet season. Pyrethroid compounds are hydrophobic and lipophilic as they accumulate more in sediment and bioaccumulate in fatty tissues. The low frequency of occurrence and concentrations in the water samples could be due to their hydrophobic nature [4, $23,25]$. They could also be present below the detection limit of the gas chromatograph. Moreover, the higher specific gravities of these pollutants could also be responsible for their very trace level in the water matrice. The mean concentration of cypermethrin of $0.01 \mu \mathrm{g} / \mathrm{L}$ in surface water samples in dry season (Table3) was lower than the EU, FAO/WHO, $0.1 \mu \mathrm{g} / \mathrm{L}[35]$ limits for pesticide residues in drinking water. It was also less than $10 \mu \mathrm{g} / \mathrm{L}$ limit set by Federal Environmental Protection Agency now Ministry of Environment in Nigeria[36]. These pollutants were not detected in surface water samples in wet season.This could be due to dilution of aquatic ecosystem. In addition,water under treatment and treated water samples were not collected during wet season sampling due to the shutdown of the water treatment plant. The level of cypermethrin in this present study was lower than the mean concentrations range of $0.48 \mu \mathrm{g} / \mathrm{L}$ to $0.93 \mu \mathrm{g} / \mathrm{L}$ reported by Akan et al., [4] on the determination of pyrethroid residues in water samples from river Benue in Vinikilang, Yola, Adamawa State, Nigeria. However, this study is in agreement with 0.005-0.021 $\mu \mathrm{g} / \mathrm{L}$ reported by Ensminger et al., [41] on pyrethroid residues in water samples from Delpueto and
Orestimba Creeks in California, USA. The contamination trend of pyrethroid pesticide residues as shown in Table-3 revealed that surface water $>$ water under treatment $>$ treated water. This shows that the effectiveness of the water treatment plant was efficient.

\section{CONCLUSION}

This study concluded that the soil, sediment and surface water of the study area were contaminated with carbamate and pyrethroid pesticide residues from agricultural practices around the river basin. The treated water from the Ondo State Water Works is however, safe for drinking due to the effectiveness of the State Water Works treatment plant. The data obtained from this study could form a baseline data for future monitoring studies at the river basin. The Federal government of Nigeria should continue to strictly enforce the laws on the safe handling and use of these chemicals for the control of pests in cocoa farms.

\section{ACKNOWLEDGEMENT}

The financial support of the Analytical Chemistry Trust Fund is appreciated.This division of the Royal Society of Chemisttry awarded Adegun Ayodeji Oluwole, the Developing World Scholarship to conduct part of his Ph.D research bench work at Kingston University, London, UK.This study forms part of his ph.D thesis.We wish to express our profound gratitude to his host supervisor, Professor James Barker.We appreciate his contributions towards the successful completion of this work. Our gratitude also goes to Dr. Peter Hooda, an associate Professor at Kingston University for his guidance, support and encouragement throughout this project. The invaluable pieces of advice of Soltani-Khankahdani Siamak of the GC/MS laboratory Section of Kingston University is also appreciated. 


\section{REFERENCES}

1. Vega, A. B., Frenich, A. G., \& Vidal, J. M. (2005). Monitoring of pesticides in agricultural water and soil samples from Andalusia by liquid chromatography coupled to mass spectrometry. AnalyticaChimicaActa, 538(1-2), 117-127.

2. Jeyaratnam, J. (1990). Acute Pesticide Poisoning: A Major Global Health Problem. World Health Stat Q. 43(3):139-44.

3. Rigotto, R.M., Da Silva, A. M. C., \& Ferreira, M. J. M. (2013). Trends of Chronic Health Effects Associated to Pesticide use in Fruit Farming Regions in the State of Ceará, Brazil. Rev Bras Epidemiol. 16(3):763-77.

4. Akan, J., Mohammed, Z., Jafiya, L., \&Audu S., (2013). Organophosphorus Pesticide Residues in Different Tissues of Fish Samples from Alau Dam, Borno State, Nigeria. World Journal of Fish and Marine Sciences. 5(5): 519-526.

5. Aiyesanmi, A. F., \&Idowu, G. A. (2012). Organochlorine Pesticides Residues in Soil of Cocoa FarmsinOndo State Central District, Nigeria. Environment and Natural Resources research. 2(2):65.

6. Tomlin, C. (1997). The Pesticide Manual, 11th ed. Surrey, UK: British Crop Protection Council.

7. Paiga, P., Morais, S., Correia. M., Alves, A., \&Delerue-Matos, C. (2009). Screening of Carbamates and Ureas in Fresh and Processed Tomato Samples using Microwave-Assisted Extraction and Liquid Chromatography. Anal Lett. (42):265-283.

8. USEPA. (2006). Human Health Issues: Pesticides. Retrieved fromhttp//www epa.gov. Assessed on 15/01/2019.

9. Amweg, E. L., Weston, D. P., You, J., \&Lydy, M. J. (2006). Pyrethroid insecticides and sediment toxicity in urban creeks from California and Tennessee. Environmental Science \& Technology, 40(5), 1700-1706.

10. Ray, D. E., \& Fry, J. R. (2006). A reassessment of the neurotoxicity of pyrethroid insecticides. Pharmacology therapeutics, 111(1), 174-193.

11. Åkerblom, N., Arbjörk, C., Hedlund, M., \&Goedkoop, W. (2008). Deltamethrin toxicity to the midge ChironomusripariusMeigen - effects of exposure scenario and sediment quality. Ecotoxicology and environmental safety, 70(1), 53-60.

12. Fosu-Mensah, B. Y., Okoffo, E. D., \&Mensah, M. (2016).Synthetic pyrethroids pesticide residues in soils and drinking water sources from cocoa farms in Ghana. Environment and Pollution, 5(1), 60.

13. Bai, J., Lu, Q., Zhao, Q., Wang, J., Gao, Z., \& Zhang, G. (2015). Organochlorine Pesticides in Wetland Soils under Different Land Uses along 100 Years Chemosequence of Reclamation of Chinese Estuary.Sci Rep. 3(5):17624.
14. Ajiboye, G. A., Jaiyeoba, J. O., Olaniyan, J. O., \&Olaiya, A. O. (2015). The characteristics and suitability of the soils of some major cocoa growing areas of Nigeria: Tung lga of Cross River. Agrosearch, 15(1), 101-116.

15. Akinifesi, T. A. (2008). Determination of Free Fatty Acids in Surface Water using a Modified Method. PhD research Thesis 2008.

16. Idowu, G. A., Aiyesanmi, A. F., \&Owolabi, B. J. (2013). Organochlorine pesticide residue levels in river water and sediment from cocoa producing area of Ondo State central senatorial district, Nigeria. Journal of Environmental Chemistry and Ecotoxicology.5(9):242-249.

17. Akoto, O., Azuure A., \&Adoteyi, A. (2016). Pesticide residues in water, sediment and fish from Tono Reservoir and their health risk implications Springer Plus. 5:1849-1860.

18. Awofolu, R., \&Fatoki, O. (2003). Persistent Organochlorine Pesticide Residues in Freshwater Systems and Sediments from the Eastern Cape, South Africa. Water SA. 29(3): 323-330.

19. Akinnawo, S. (2015). Concentration of Organophosphorous Pesticide Residues in Water and Sediment Samples from River Ilaje, Nigeria. American Chemical Science Journal. 11(1):1-9.

20. Fatoki, O. S., \&Awofolu, R. O., (2004). Levels of Organochlorinss Pesticides Residues in Marine, Surface Ground and Drinking Waters from Eastern Cape Province of South Africa. Journal of Environmental Science and Health. 39(1):101114.

21. Ezeemonye, L., Ikpesu, T., \&Tongo, J. (2005). Distribution of lindane in water, sediment and fish from Warri river of the Niger Delta, Nigeria. J for Institute for Medical Research and Occupational Health. 59(4).

22. Asogwa, E., \&Dongo, L. (2009). Problems Associated with Pesticide Usage and Application in Nigerian Cocoa Production: A review. African Journal of Agricultural Research. 4(8):675-683.

23. Sagratini, G., Mañes, J., Giardiná, D., Damiani, P., \&Picó, Y., (2007). Analysis of Carbamate and Phenylurea Pesticide Residues in Fruit Juices by Solid-Phasemicroextraction and Liquid Chromatography-Mass Spectrometry. J Chromatogr A. (1147): 135-143.

24. Wabel, M. H., El-Saeid, A. M., Turki-Al., \& Abdel-Nasser, G. (2011). Monitoring of Pesticide Residues in Saudi Arabia Agricultural Soils. Research Journal of Environmental Sciences. 15(5):269-278.

25. Pérez, J. J., Williams, M. K., Weerasekera, G., Smith, K., Whyatt, R. M., Needham, L. L., \& Barr, D. B. (2010). Measurement of pyrethroid, organophosphorus, and carbamate insecticides in human plasma using isotope dilution gas chromatography-high resolution mass spectrometry. Journal of Chromatography B, 878(27), 2554-2562. 
26. Müller-Mohnssen, H. (1999). Chronic Sequelae and Irreversible Injuries Following Acute Pyrethroid Intoxication. ToxicolLett. 107(13):161-176.

27. Giri, S., Giri, A., Sharma, G. D., \& Prasad, S. B. (2003). Induction of Sister Chromatid Exchanges by Cypermethrin and Carbosulfan in Bone Marrow Cells of Mice. In vivo.Mutagenesis. 18(1): 53-58.

28. Patel, S., Pandey A. K., Bajpayee, M., Parmar, D., \&Dhawan, A. (2006). Cypermethrin induced DNA damage in organs and tissues of the mouse: evidence from the comet assay. Mutat Res. 607:176-183.

29. Shukla, Y., Yadav, A., \&Arora, A. (2002). Carcinogenic and Co-carcinogenic Potential of Cypermethrin on Mouse Skin. Cancer Lett. 182(1): 33-41.

30. Palmquist, K., Salatas, J., \&Fairbrother, A. (2012). Pyrethroid Insecticides: Use, Environmental Fate, and Ecotoxicology, Insecticides-Advances in Integrated Pest Management. FarzanaPerveen (Ed.). Available from: http://www.intechopen.com/books/insecticidesadvances-in-integrated-pestmanagement/pyrethroidinsecticides-useenvironmental-fate-and-ecotoxicology. Accessed on $12 / 8 / 2018$.

31. Luo, Y., \& Zhang, M. (2011). Environmental Modeling and Exposure Assessment of SedimentAssociated Pyrethroids in an Agricultural Watershed. PLoS ONE. 6(1): e15794. https://doi.org/10.1371/journal.pone.0015794

32. Maximum Residue And Maximum Residue Levels'Director, Establishment Inspection Directorate, NAFDAC at the Workshop On Pesticide Maximum Residue Levels (MRL) held in Alexandria Egypt. 30 ${ }^{\text {th }}$ March to $2^{\text {nd }}$ April 2009.

33. US Environmental Protection Agency (US EPA), Method 3510, Revision C Washington DC, USA. 2007.
34. US Environmental Protection Agency (US EPA), Method 3550 Revision C Washington DC, USA. 2007.

35. European Union, MRLs Sorted by Pesticide. European Union (2008). [Online] Available: http://ec.europa.eu/sanco pesticides/public/index.cfm Accessed 09 September, 2014.

36. Federal Environmental Protection Agency. (FEPA) Now Federal Ministry of Environment. Guidelines and Standards for Environmental Pollution Control in Nigeria. Retrieved from www.placng.org/new/laws/F10. 1991. Accessed 12/10/2018.

37. Food and Agriculture Organization of the United Nations (2002). International Code of Conduct on the Distribution and Use of Pesticides. Retrieved from www.fao./code. Accessed on 20/11/2018.

38. US Environmental Protection Agency (USEPA). Methods, 8081B, Section 11.,11 .4.5 Revision, 2007.

39. Ibigbami, A., Aiyesanmi, A., Adeyeye, E., Adebayo, A., \&Aladesanwa, D. (2015). Assessment of Organochlorine and Organophosphorus Pesticide Residues in Water and Sediments from Ero River in South Western, Nigeria. Journal of Chemical, Biological and Physical Science (JCBPS). 5(4): 4679-4689.

40. Jabeen, F., Chaudhry A.S, Manzoor, S., \&Shaheen, T. (2015). Examining Pyrethroids, Carbamates and Neonicotenoids in Fish, Water and Sediments from the Indus River for Potential Health Risks. Environmental Monitoring and Assessment. 187(2): 29.

41Ensminger, M.,Bergin, R., Spurlock, F., (2009. Pesticide Concentrations in Water, Sediment Invertebrate Toxicity in Del Puerto and OrestimbaCreeks,California.(Availableonhttp://www.cd pr.ca.gov/docs/emon/pubs/ehapreps.htm.Accessed on 12/07/18). Sacramento, CA: California Environmental Protection Agency, Department of Pesticide Regulation 